University of Nebraska - Lincoln

DigitalCommons@University of Nebraska - Lincoln

Faculty Publications from the Harold W. Manter Laboratory of Parasitology

$12-1-1988$

\title{
Coccidia (Apicomplexa: Eimeriidae) from the Subterranean Rodent Ctenomys opimus Wagner (Ctenomyidae) from Bolivia, South America
}

\author{
Christine R. Lambert \\ University of New Mexico \\ Scott Lyell Gardner \\ University of Nebraska - Lincoln, slg@unl.edu \\ Donald Duszynski \\ University of New Mexico, eimeria@unm.edu
}

Follow this and additional works at: https://digitalcommons.unl.edu/parasitologyfacpubs

Part of the Parasitology Commons

Lambert, Christine R.; Gardner, Scott Lyell; and Duszynski, Donald, "Coccidia (Apicomplexa: Eimeriidae) from the Subterranean Rodent Ctenomys opimus Wagner (Ctenomyidae) from Bolivia, South America" (1988). Faculty Publications from the Harold W. Manter Laboratory of Parasitology. 15.

https://digitalcommons.unl.edu/parasitologyfacpubs/15

This Article is brought to you for free and open access by the Parasitology, Harold W. Manter Laboratory of at DigitalCommons@University of Nebraska - Lincoln. It has been accepted for inclusion in Faculty Publications from the Harold W. Manter Laboratory of Parasitology by an authorized administrator of DigitalCommons@University of Nebraska - Lincoln. 


\title{
COCCIDIA (APICOMPLEXA: EIMERIIDAE) FROM THE SUBTERRANEAN RODENT CTENOMYS OPIMUS WAGNER (CTENOMYIDAE) FROM BOLIVIA, SOUTH AMERICA
}

\author{
Christine R. Lambert, Scott L. Gardner, and Donald W. Duszynski \\ Department of Biology, The University of New Mexico, Albuquerque, New Mexico 87131
}

\begin{abstract}
Of 35 tuco-tucos (Ctenomys opimus) collected in Bolivia, South America, 31 (88\%) had eimerian oocysts in their feces at the time they were examined. Eighteen $(58 \%)$ of the 31 infected animals were concurrently infected with 2 or 3 eimerian species. Four species of Eimeria were recovered and are described as new species based on the characteristics of sporulated oocysts. Oocysts of Eimeria granifera $\mathrm{n}$. sp. were ellipsoidal, $21.1 \times$ $17.2(15-26 \times 11-20) \mu \mathrm{m}$ with sporocysts ovoidal, $11.3 \times 7.1(8-14 \times 5-9) \mu \mathrm{m}$. Oocysts of Eimeria montuosi n. sp. were spheroidal, $24.2 \times 22.0(21-28 \times 18-25) \mu \mathrm{m}$ with sporocysts ovoidal, $10.5 \times 7.3(8-14 \times 6-9) \mu \mathrm{m}$. Oocysts of Eimeria opimi n. sp. were spheroidal to subspheroidal, $24.3 \times 21.8(18-29 \times 15-26) \mu \mathrm{m}$ with sporocysts ovoidal, $11.6 \times 7.6(10-13 \times 6-9) \mu \mathrm{m}$. Oocysts of Eimeria oruroensis $\mathrm{n}$. sp. were spheroidal to subspheroidal, $27.3 \times 23.6(23-32 \times 20-28) \mu \mathrm{m}$ with sporocysts ovoidal, $13.2 \times 8.6(10-16 \times 8-11) \mu \mathrm{m}$.
\end{abstract}

The Ctenomyidae is 1 of 11 families belonging to the suborder Hystricognathi (see Mares and Ojeda, 1982). The geologic age of the family is Pliocene to Recent in South America (Nowack and Paradiso, 1983). Relatively little is known of the endoparasite fauna of these subterranean rodents, and, until the present paper, no coccidia had been reported from this group of mammals. Since 1984, fecal samples, helminths, ectoparasites, and other data (skin, skeleton, chromosomes, tissues for electrophoresis) have been collected from several populations of Ctenomys opimus Wagner from various localities in western Bolivia, South America (Fig. 1). In these hosts we found sporulated oocysts representing 4 new species of Eimeria, which we describe here.

\section{MATERIALS AND METHODS}

All hosts were necropsied in the field promptly after capture. Organs were examined for the presence of metazoan parasites and fecal pellets were removed from the lower bowel of each animal and preserved in vials containing $2.0 \%$ aqueous $(w / v) \mathrm{K}_{2} \mathrm{Cr}_{2} \mathrm{O}_{7}$. Upon return from Bolivia, samples were filtered and the fecal debris was then incubated at room temperature $(24 \mathrm{C})$ for 20 days. Samples were then examined by coverslip flotation as described by Duszynski et al. (1982). Oocysts were measured with an ocular micrometer and photographed with Panatomic-X 35-mm film within a Zeiss Universal Photomicroscope equipped with both Neofluar and Nomarski-interference $100 \times$ objective lenses. All measurements are in $\mu \mathrm{m}$ with the ranges in parentheses.

Received 30 May 1988; revised 10 July 1988; accepted 21 July 1988.

\section{RESULTS}

The coccidians with which hosts were infected and collection localities are presented in Table I.

Eimeria granifera $\mathbf{n}$. sp.

(Figs. 2, 3, 11)

Description: Oocyst subspheroidal/ellipsoidal, wall of uneven thickness (Fig. 2) 2.0, composed of 2 layers: outer wall smooth, $\sim 3 / 4$ of total thickness, pale blue to transparent; inner layer yellow; polar body present in about $44 \%$ of the oocysts; oocyst residuum absent; sporulated oocysts $(n=75) 21.1 \times 17.2(15-26 \times 11-$ $20)$ with $L: W$ ratio $1.2(1.1 \times 1.9)$; sporocysts $(n=75)$ ovoidal, $11.3 \times 7.1(8-14 \times 5-9)$ with $\mathrm{L}: \mathrm{W}$ ratio 1.6 $(1.2 \times 2.0)$; button-like Stieda body present (Figs. 2, 3), but sub- and parastieda bodies absent; sporocyst residuum of 10-12 large globules in a compact mass of varying shape, wedged between sporozoites (Figs. 2, 3 ); each sporozoite large, folded, highly granular with a large posterior refractile body (Figs. 3, 11). Oocysts were 274-275 days old when measured.

\section{Taxonomic summary}

Diagnosis: Oocysts of this eimerian do not resemble those from any eimerian previously described from New World hystricognath rodents.

Type host: Ctenomys opimus Wagner, Museum of Southwestern Biology, Division of Mammalogy, MSB 57200, NK 14776 (female), N. Olds \#980, 3 Oct 1986.

Type locality: $3 \mathrm{~km} \mathrm{~W}$ of Huancaroma, Rio Desaguadero, 3,720 m, Department of Oruro, Bolivia, South America $\left(17^{\circ} 40^{\prime} \mathrm{S}, 61^{\circ} 31^{\prime} \mathrm{W}\right)$.

Prevalence: Found in 23 of 35 (66\%) C. opimus.

Site of infection: Unknown, oocysts recovered from feces.

Material deposited: Syntypes (=phototypes, see Bandoni and Duszynski, 1988) of sporulated oocysts, USNM Helm. Coll. No. 80445.

Etymology: The nomen triviale is derived from the word granifer (L., grain-carrying); this is descriptive of the highly granular sporozoites. 


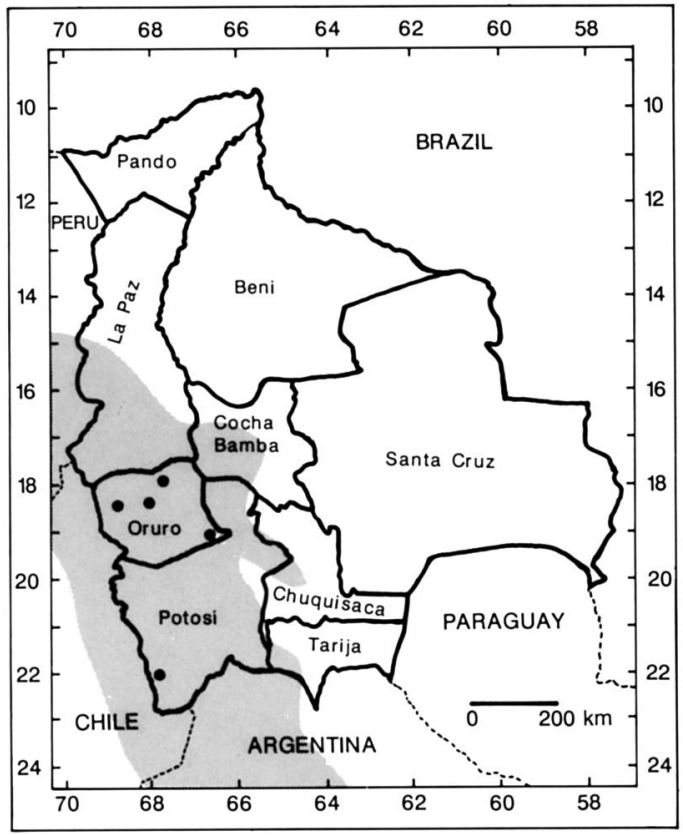

FIGURE 1. Map of Bolivia, South America, showing its contiguous neighbors and the arrangement of its Departments (states). Shaded area shows the distribution of Ctenomys opimus. Dots represent collection localities.

\section{Eimeria montuosi n. sp.}

(Figs. 4, 12)

Description: Oocysts spheroidal or nearly so with thick wall $\sim 3.0$, consisting of 2 or 3 layers: outer layer having large protruding bumps on the surface, yellow to gold, $\sim 3 / 4$ of the total thickness (Fig. 4 , insert); oocyst residuum a compact mass of large granules, $\sim 6$; polar body absent; sporulated oocysts $(n=42) 24.2 \times 22.0$ $(21-28 \times 18-25)$ with L:W ratio $1.1(1.0 \times 1.2)$; sporocysts $(n=42)$ ovoidal, $10.5 \times 7.3(8-14 \times 6-9)$ with $\mathrm{L}: \mathrm{W}$ ratio $1.4(1.2 \times 1.9)$; sporocysts with small Stieda body, but sub- and parastieda bodies absent; sporocyst residuum consisting of 6 or more small globules separating the sporozoites. Oocysts were 298-330 days old when measured.

\section{Taxonomic summary}

Diagnosis: Oocysts of this eimerian do not resemble those from any eimerian previously described from New World hystricognath rodents.

Type host: Ctenomys opimus Wagner, Museum of Southwestern Biology, Division of Mammalogy, MSB 57202, NK 14559 (female), N. Olds \#861, 12 Sep 1986.

Type locality: $5 \mathrm{~km} \mathrm{~W}, 1 \mathrm{~km}$ N Pomata Ayte, Rio Barros, Department of Oruro, Bolivia, South America (18 $\left.40^{\prime} \mathrm{S}, 67^{\circ} 59^{\prime} \mathrm{W}\right)$.

Prevalence: Found in 1 of 35 (3\%) C. opimus.

Site of infection: Unknown, oocysts recovered from feces.

Material deposited: Syntypes (phototypes) of sporulated oocysts, USNM Helm. Coll. No. 80446.
TABLE I. Eimeria spp. recovered from 35 Ctenomys opimus from the western high altitude of Bolivia, South America.

\begin{tabular}{lcl}
\hline $\begin{array}{l}\text { Department: } \\
\text { Location }\end{array}$ & $\begin{array}{c}\text { No. hosts } \\
\text { infected/ } \\
\text { examined (\%) }\end{array}$ & \multicolumn{1}{c}{ Eimeria spp. } \\
\hline $\begin{array}{l}\text { Oruro: } \\
\text { Cruce Ventilla }\end{array}$ & $5 / 6(83)$ & $\begin{array}{l}\text { opimi, granifera } \\
\text { Estancia Agua Rica }\end{array}$ \\
Huancaroma & $0 / 1(0)$ & $\begin{array}{l}\text { opimi, granifera, } \\
\text { oruroensis }\end{array}$ \\
Pomata Ayte & $18 / 19(95)$ & $\begin{array}{c}\text { montuosi } \\
\text { mimi, granifera, }\end{array}$ \\
Potosi: & $4 / 5(80)$ & opimi, granifera \\
La Laguna & & 4 \\
Totals (5 locations) & $31 / 35(88)$ & \\
\hline
\end{tabular}

Etymology: The nomen triviale is derived from the word montuosus (L., mountainous); this is descriptive of the large protruding bumps on the surface of the oocyst wall.

\section{Eimeria opimi n. sp.}

(Figs. 5-7, 13)

Description: Oocyst spheroidal to subspheroidal, wall $\sim 1.5$, composed of at least 2 layers: outer layer finely sculptured (Fig. 7, insert), $\sim 3 / 4$ of total thickness, colorless to pale blue; inner layer smooth, transparent to pale blue; dumbbell-shaped polar body present (Fig. 5 ); oocyst residuum $(\sim 5.3)$ composed of 8-10 uniform granules in a compact mass (Fig. 6); sporulated oocysts $(\mathrm{n}=55) 24.3 \times 21.8(18-29 \times 15-26)$ with $\mathrm{L}: \mathrm{W}$ ratio $1.1(1.0 \times 1.7)$; sporocysts $(\mathrm{n}=55)$ ovoidal, $11.6 \times$ $7.6(10-13 \times 6-9)$ with $\mathrm{L}: \mathrm{W}$ ratio $1.5(1.3 \times 1.9)$; nipple-like Stieda body present (Figs. 5-7), but suband parastieda bodies absent; sporocyst residuum of 2-3 granules (Fig. 7) separating the sporozoites; each sporozoite transparent with large posterior refractile body (Fig. 7). Oocysts were 1,024-1,025 days old when measured.

\section{Taxonomic summary}

Diagnosis: Oocysts of this eimerian do not resemble those from any species previously described from New World hystricognath rodents.

Type host: Ctenomys opimus Wagner, Museum of Southwestern Biology, Division of Mammalogy, MSB 55372, NK 11564 (male), J. A. Cook \#1264, 6 Aug 1984.

Type locality: $2.5 \mathrm{~km}$ NE of Huancaroma, Department of Oruro, Bolivia, South America $\left(17^{\circ} 40^{\prime} \mathrm{S}\right.$, $\left.67^{\circ} 27^{\prime} \mathrm{W}\right)$

Prevalence: Found in 28 of $35(80 \%)$ C. opimus. Site of infection: Unknown, oocysts recovered from feces.

Material deposited: Syntypes (phototypes) of sporulated oocysts, USNM Helm. Coll. No. 80447.

Etymology: The nomen triviale is derived from the specific name of the host.

\section{Eimeria oruroensis n. sp.}

(Figs. 8-10, 14)

Description: Oocyst spheroidal to subspheroidal, wall 2.3-3.0, composed of at least 3 layers: outer wall rough 


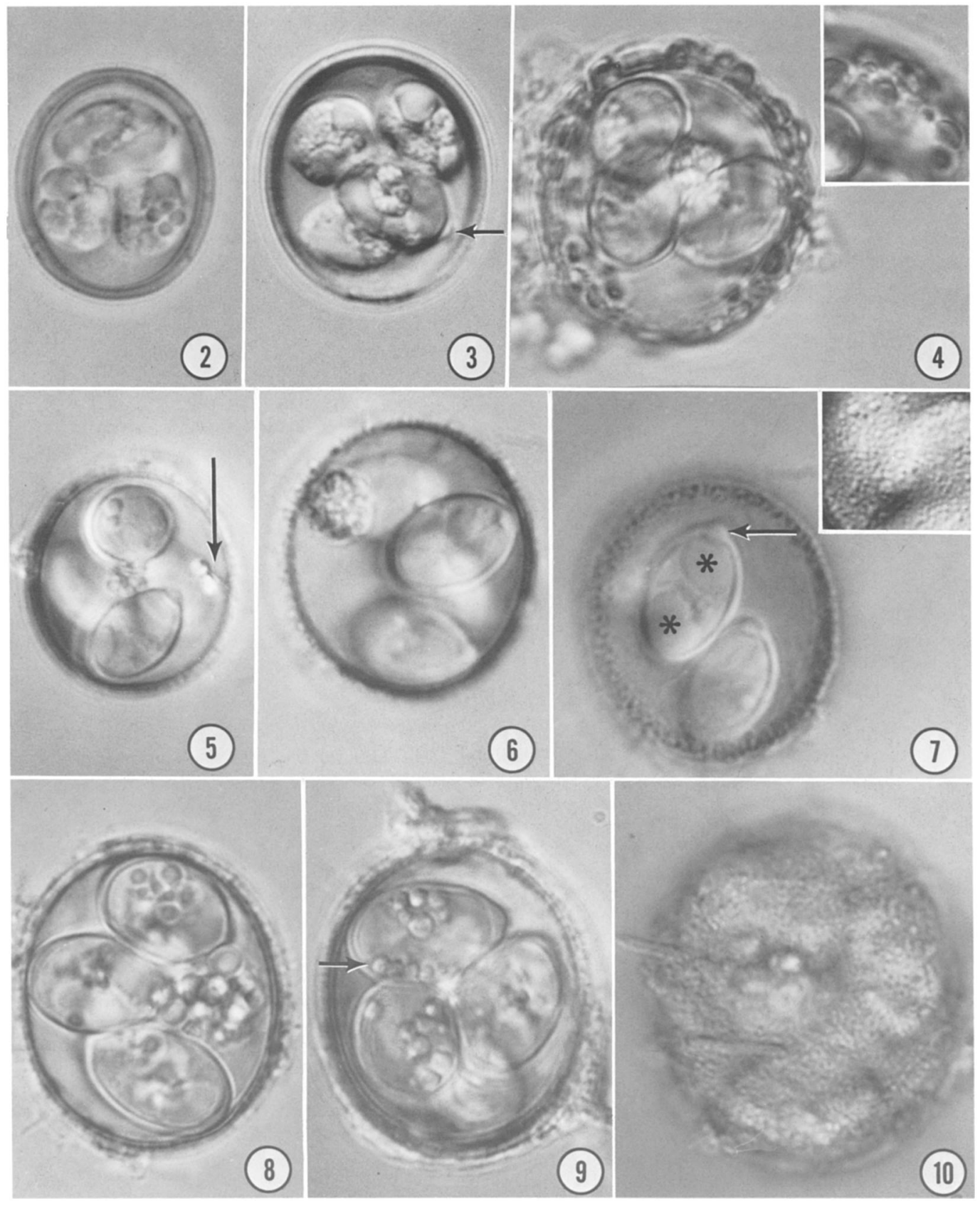

FIGURES 2-10. Photomicrographs of sporulated oocysts of coccidia recovered from the feces of Ctenomys opimus. $\times 1,860$. 2, 3. Eimeria granifera $\mathrm{n}$. sp. Note button-like Stieda body (3, arrow), sporocysts residuum (2), and large, folded, highly granular sporozoites with large posterior refractile body. 4. Eimeria montuosi n. sp. Note large, protruding bumps on surface of oocyst. 5-7. Eimeria opimi $\mathrm{n}$. sp. 5. Note dumbbell-shaped polar body (arrow). 6. Sporulated oocyst showing compact oocyst residuum. 7. Sporocysts with nipple-like Stieda body (arrow), large posterior refractile body $\left({ }^{*}\right)$, and finely sculptured nature of oocyst wall (insert). 8-10. Eimeria oruroensis $\mathbf{n}$. sp. 8. Sporulated oocyst showing oocyst residuum in a loosely packed mass. 9. Sporocyst residuum forming a line along sporocyst wall (arrow), and separating the 2 sporozoites. 10. Sculptured nature of oocyst wall. 

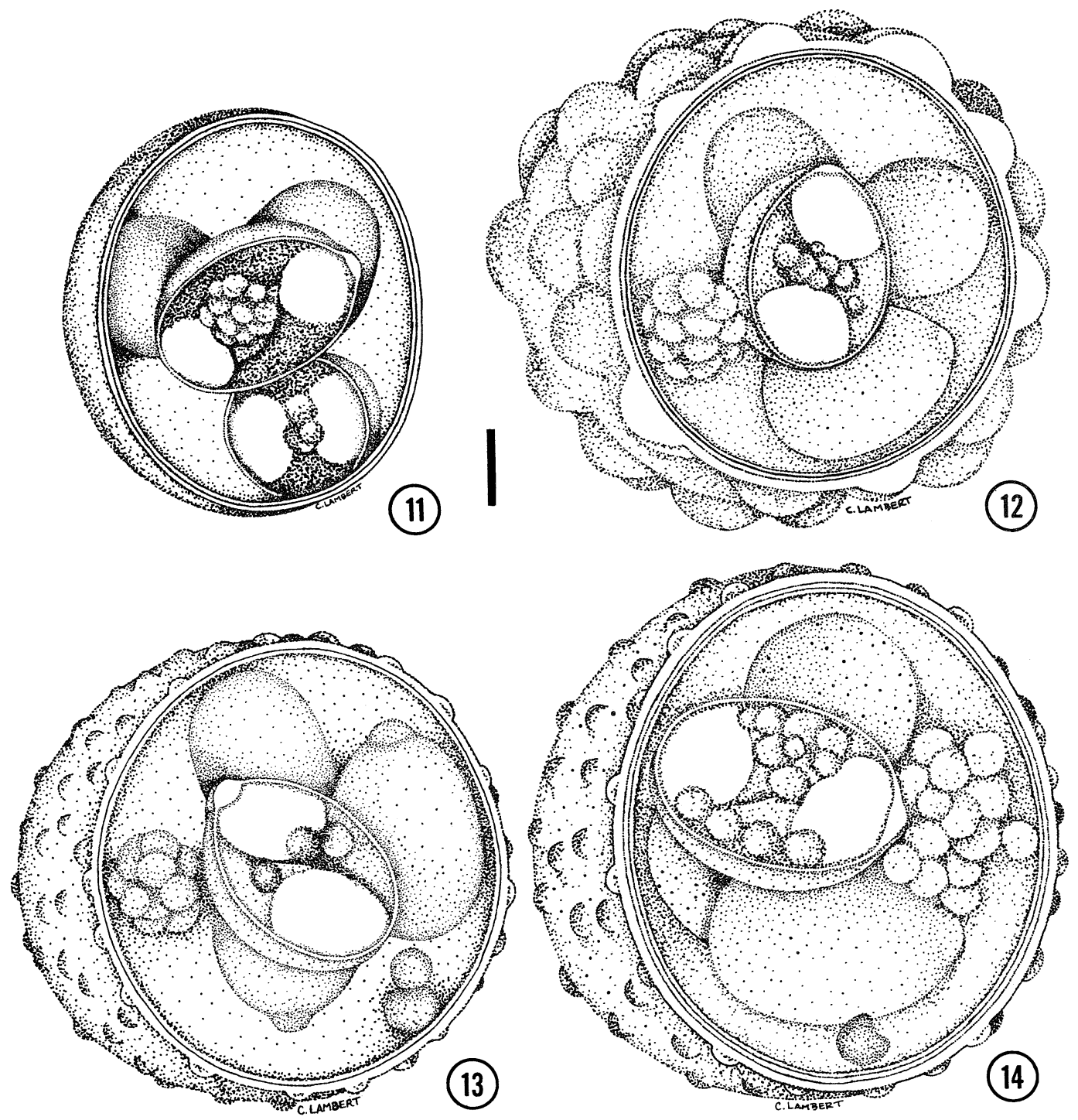

FIGUREs 11-14. Line drawings of sporulated oocysts of coccidia recovered from the feces of Ctenomys opimus; bar $=3 \mu \mathrm{m}$. 11. Eimeria granifera. 12. Eimeria montuosi. 13. Eimeria opimi. 14. Eimeria oruroensis.

(Fig. 10), $3 / 4$ of total thickness, yellow to gold, always with adherent debris; middle layer pale yellow in color; innermost layer dark brown; polar body present; oocyst residuum ( 9) composed of 10-15 globules of varying size in a loosely packed mass (Fig. 8); sporulated oocysts $(\mathrm{n}=50) 27.3 \times 23.6(23-32 \times 20-28)$ with $\mathrm{L}: \mathrm{W}$ ratio $1.2(1.0 \times 1.7)$; sporocysts $(\mathrm{n}=50)$ ovoidal, $13.2 \times$ $8.6(10-16 \times 8-11)$ with $\mathrm{L}: \mathrm{W}$ ratio $1.5(1.2 \times 1.8)$; Stieda body present, but sub- and parastieda bodies absent; sporocyst residuum consists of large globules of varying shape and size separating the 2 sporozoites or forming a line along the sides of the sporocyst wall (Figs. 8, 9); each sporozoite with a posterior refractile body. Oocysts were 1,023-1,035 days old when measured.

\section{Taxonomic summary}

Diagnosis: Oocysts of this eimerian do not resemble those from any species previously described from New World hystricognath rodents.

Type host: Ctenomys opimus Wagner, American Museum of Natural History, Division of Mammalogy, AMNH 260840, NK 11514 (male), S. Anderson \#7890, 4 Aug 1984.

Type locality: $3.5 \mathrm{~km}$ E of Huancaroma, Department of Oruro, Bolivia, South America $\left(17^{\circ} 40^{\prime} \mathrm{S}\right.$, $\left.67^{\circ} 27^{\prime} \mathrm{W}\right)$.

Prevalence: Found in 1 of $35(3 \%)$ C. opimus.

Site of infection: Unknown, oocysts found in feces.

Material deposited: Syntypes (phototypes) of sporulated oocysts, USNM Helm. Coll. No. 80444. 
Etymology: The nomen triviale combines the name of the department in Bolivia in which the infected host was caught and -ensis (L., belonging to).

\section{DISCUSSION}

The genus Ctenomys Blainville includes approximately 33 currently recognized species (Honacki et al., 1982). These rodents occur in suitable habitats from about $10^{\circ} \mathrm{S}$ latitude southward to the Strait of Magellan. Ctenomys opimus has one of the most extensive geographic distributions compared to other members of the genus (Fig. 1). Colonies occur at altitudes up to $>4,000$ $\mathrm{m}$ in the altiplano region of Bolivia and in habitats characterized as Puna and high altitude desert of Peru, Bolivia, Chile, and Argentina (Gallardo, 1979; Mares and Ojeda, 1982). Ctenomys opimus is a strictly subterranean species with populations occurring in small isolated areas throughout their range in Bolivia (Gardner, pers. obs.). These rodents display some of the same ecological and morphological attributes as other subterranean rodents (Nevo, 1979). For example, members of the genus Thomomys WeidNeuwied in the Nearctic exhibit low vagility, relatively low density, and patchy distributions (Patton, 1972).

Up to the present, the coccidia of Ctenomys have not been studied, and the number of species that exist of both host and parasite and their phylogenetic and coevolutionary relationships are unknown. Pellérdy (1974) listed 23 described species of Eimeria from hystricognath rodents; however, none of those listed are from the host Ctenomys, nor do they resemble the eimerian: described in the present paper.

At present we are analyzing the coccidians from 9 other species of Ctenomys. In subsequent papers, we hope to discuss the patterns and processes of speciation, diversification, and coevolution among members of the genus Ctenomys and their parasites.

\section{ACKNOWLEDGMENTS}

We are indebted to the following colleagues in the Department of Biology, The University of
New Mexico, and elsewhere for their help in the collection and/or processing of tuco-tucos: J. A. Cook, C. Schuster, N. Olds, J. S. Salazar, J. M. Goytia, Dr. T. L. Yates, Dr. S. Anderson, and, especially, Dr. O. C. J. Camacho. We also thank J. A. Cook for reviewing the manuscript. This work was supported by NSF grant BSR-8408923 to Dr. T. L. Yates.

\section{LITERATURE CITED}

Anderson, S., T. L. Yates, AND J. A. CoOK. 1987. Notes on Bolivian mammals 4: The genus Ctenomys (Rodentia, Ctenomyidae) in eastern lowlands. American Museum Novitates 2891: 1-20.

BANDONI, S. M., AND D. W. DuSZYNSKI. 1988. A plea for improved presentation of type material for coccidia. Journal of Parasitology 74: 519-523.

Duszynski, D. W., G. EAstham, and T. L. YATES. 1982. Eimeria from jumping mice (Zapus spp.): A new species and genetic and geographic features of Z. hudsonicus luteus. Journal of Parasitology 68: $1146-1148$.

Gallardo, M. 1979. Las especies chilenas de Ctenomys (Rodentia, Octodontidae). I. Estabilidad cariotipica. Archivos de Biologia y Medicina Experimentales 12: 71-82.

HoNACKI, J. H., K. E. KINMAN, AND J. W. KoEPPL (eds.). 1982. Mammal species of the world: A taxonomic and geographic reference. Allen Press, Inc., and the Association of Systematics Collections, Lawrence, Kansas, 694 p.

MARES, M. A., AND R. A. OJEDA. 1982. Patterns of diversity and adaptation in South American hystricognath rodents. In Mammalian biology in South America, M. A. Mares and H. H. Genoways (eds.). Special Publication No. 6 of The Pymatuning Symposium in Ecology, University of Pittsburg, pp. 393-432.

Nevo, E. 1979. Adaptive convergence and divergence of subterranean mammals. Annual Review of Ecology and Systematics 10: 269-308.

NowaK, R. M., AND J. L. Paradiso. 1983. Walker's mammals of the world, 4 th ed., 2 vols. The Johns Hopkins University Press, Baltimore and London, $1,362 \mathrm{p}$.

Patton, J. L. 1972. Patterns of geographic variation in karyotype in the pocket gopher, Thomomys bottae (Eudoux and Gervais). Evolution 26: 574-586.

Pellérdy, L. P. 1974. Coccidia and coccidiosis, 2nd ed. Verlag, Paul Parey, Berlin, 959 p. 